\title{
Geochronology of the Karasjok
}

Greenstone Belt establishes the

2.22-2.06 Ga Lomagundi age for the

Corgaš Formation carbonates with highly positive carbon isotope values

\author{
H. HANSEN ${ }^{1}$, T. Slagstad ${ }^{2}$, A. BEKKER ${ }^{3}$, S. G. BERGH ${ }^{1}$
}

${ }^{1}$ UiT The Arctic University of Norway, 9037 Troms $\varnothing$,

Norway, harald.hansen@uit.no

${ }^{2}$ Geological Survey of Norway, 7491 Trondheim, Norway

${ }^{3}$ Department of Earth \& Planetary Sciences, University of California, Riverside, CA, 92521 USA

The Karasjok Greenstone Belt (KGB) of NE Norway is situated in the northern part of the Fennoscandian Shield. The stratigraphy includes four formations in the ascending order: 1) Lavttevárri Formation (siliciclastic sediments overlain by komatiites, tholeiites, and rhyolites); 2) Corgaš Formation (psammites overlain by tholeiites, schists, and carbonates); 3 ) Briittágielas Formation (mafic volcanics interlayered with komatiites and schists); and 4) Fossestrand Formation of komatiites. Melezhik et al. (2015) found that carbonates in the upper Corgaš Formation have $\delta^{13} \mathrm{C}$ values of +8 to $+14 \%$, suggesting that these carbonates could record the $\sim 2.22-2.06$ Ga Lomagundi carbon isotope excursion (LCIE). Until now, there were no reliable geochronology data to confirm this.

We sampled all main units to geochronologically constrain their ages. The U-Pb zircon ages for the Jergul Complex are 3.0 to $2.8 \mathrm{Ga}$. Based on the U-Pb crystallization age of the Karinhaugen intrusion $(2721 \pm 11 \mathrm{Ma})$, the Lavttevárri Formation is bracketed in age between 2.8 and 2.72 Ga. Detrital zircons from the Corgaš Formation psammites provide maximum age for deposition of $2.8 \mathrm{Ga}$. A layered intrusion above the lowest carbonate unit gave an age of $2147 \pm 17 \mathrm{Ma}$ and a granitic dike in the upper part of the Corgaš Formation is $2039 \pm 11 \mathrm{Ma}$ in age. An intermediate volcanic unit of the Briittágielas Formation yielded a U-Pb age of $1949 \pm 10 \mathrm{Ma}$.

The results show that tectonostratigraphically the KGB can be divided into three distinctive successions. The Archaean Lavttevárri Formation is a possible age-equivalent with the Goldenvárri Formation in the Kautokeino Greenstone Belt and with the whole succession of the Kuhmo-SuomussalmiTipasjärvi Greenstone Belt in Finland. The geochronology of the Corgaš Formation confirms that its carbonates have been deposited during the LCIE. The Briittágielas Formation likely records an early stage of the Lapland-Kola orogeny.

Melezhik et al., 2015, Nor. J. Geol., 95, 299-314. 